International Journal of Engineering \& Technology, $9(2)(2020) 552-559$
International Journal of Engineering \& Technology
SPC
Website: www.sciencepubco.com/index.php/IJET
Research paper

\title{
The effect of project owners, plan-developers and characteristics of projects on airport building performance
}

\author{
Reiza Irfansyah $^{1 *}$, Budi Susetyo ${ }^{2}$, Syafwandi ${ }^{2}$ \\ ${ }^{1}$ Students of the Civil Engineering Masters Program at Mercu Buana University \\ ${ }^{2}$ Lecturer in Civil Engineering, Mercubuana University \\ *Corresponding author E-mail: reizairfansyah87@gmail.com
}

\begin{abstract}
The concept of Design and Build quickly becomes the preferred form of project completion. With this concept, it is possible for a project to be completed more quickly, with quality and costs according to plan. However, based on the results of research on construction projects in Jakarta, there are many that do not meet expectations.

This study aims to determine the relationship of project owner factors, planner-builder factors, and project characteristics on airport design projects. Based on PLS SEM analysis of 65 respondents, it was found that the factor of the project owner has a positive but not significant effect on the performance of the Airport project, the builder planner has a negative but not significant effect on the performance of the Airport project, while the project characteristics factor has a positive and significant effect on project performance Airport.

The results of this study provide confirmation and direction in the work of design projects in the future, especially for design projects at the airport.
\end{abstract}

Keywords: Project Design; Project Owner; Project Planner; Project Characteristics; Project Performance.

\section{Introduction}

With changes in the era of globalization, the aviation world has become more affordable, making passenger growth accelerate which has an effect on increasing the number of air transportation modes which has resulted in increased infrastructure capacity and the use of air and land side facilities at airports. Indonesia in recent years has been aggressively building airport infrastructure. President Joko Widodo reasoned, the construction of airports throughout Indonesia would be able to increase economic growth. Company has also allocated capital expenditure of Rp. 11 trillion in 2019 (cnbcindonesia.com, 2019). To speed up the process, the planned design of the system is planned.

The Ministry of Public Works and Public Housing (PUPR) as the organizer of infrastructure works stated that it has implemented the Design and Build method or an integrated design project. The method is considered more efficient in terms of time and cost than the conventional Design Bid and Build method (bisnis.com, 2016).

In the USA, for nearly 20 centuries, the concept of design has been classified as a non-traditional construction method. However, the concept of design and build quickly became the most preferred form of project completion, which increased rapidly from initially only around $5 \%$ for the construction of non residential projects in 1985, to $40 \%$.

Based on the observations of the authors from the research project design journal sources, among others: Andi M.Tarigan (2018) shows that the total rehabilitation project for educational buildings in package 4 in DKI Jakarta province with a design and build system, can be completed sooner than the specified time with quality according to specifications and does not change costs.

Project scope factors have a very low relationship, Owner management ability, implementation ability and Project manager ability have a low relationship, planning ability has a sufficient relationship, while the Procurement process factor has a high relationship to the success of the total education building rehabilitation project in package 4 in the province DKI Jakarta. The design and build risk factors all have a significant effect on the success of the project by $69.8 \%$. The dominant factor influencing project success is the procurement process factor.

Research by Toni Alam shows the fast execution time of work is the reason why design and build projects are used at PT XYZ but in implementation there are always delays in work. Preparation of variables from secondary data and literature studies, expert validation, pilot surveys, distribution of questionnaires to respondents, then evaluated with comparative analysis, descriptive, validity and reliability tests, correlations, factor analysis and linear regression, finally obtained the three most significant risk factors namely : lack of experience of the design team and project manager in preparing the implementation schedule and handling the complexity of the TOR and the scope 
of work: lack of competence in carrying out the work in realizing design and build work; and negligence and delays from subcontractors. From the regression equation, risk factors are correlated with time performance and risk factors reduce time performance [1].

Research by Bambang E. Yuwono (2008) models the interaction of various factors that influence the success of the design project then is modeled and tested using the SEM (Structural Equation Modeling) methodology to describe, quantify and demonstrate the effect of the interaction of various factors on the success of the design project. From the results of this study it can be revealed that the critical success factors of the design project are the factors that have direct and dominant influence on the success of the design project, namely the ability of the management of the project owner (Owner), the ability of the management of the design team, the symbiosis between the project owner and the design team. The symbiosis between the project owner and the design team is dominated by defining the scope of the project [2]

in this study project ownership was measured by the extent to which the role of the project owner from the way project control and supervision in the project so that it is measured by the scale of behavior.

The structure of this paper is organized as follows: the next section presents the characteristics of the multi-echelon system considered in this work. A brief literature devoted to simulation of multi-echelon distribution system is provided in section 3 . Section 4 presents analysis of MEDS processes and describes step by step the designing and the implementation of the simulation model. The initial conditions and parameters of the developed simulation model are presented in section 5. The section 6 presents the results and discusses the major findings of the proposed eight experimentation scenarios. The paper concludes with the advantages of the developed simulation model.

\section{Teoretical review}

\subsection{Build design}

Design and Build, can be defined as a procurement with a single contract system between the project owner (owner), with a construction implementation team that is responsible for carrying out the design and construction process as well as efficiently. The design of the building is simpler in the process, when compared to the traditional method called design bid build, where the design process and construction implementation are clearly separated by the work contract. Design and build is a terminology that underlies the term contract work package, full service, development and development [3].

According to Toni Alam (2011) For building design projects, the type of work is more specific to construction work and public buildings, where the contractor can collaborate with the planning consultant in carrying out the work, or involve the contractor's own planners if the company has experts in planning (in- house consultant). the design and build scheme of the work owner will usually involve a consultant to oversee the work of the contractor [5].

Based on a research study conducted by Pennsylvania State University in collaboration with the Construction Industry Institute of 351 projects in 37 US states (Source: Project Delivery Institute, 1999), the following conclusions are summarized:

- The design build method provides a $6 \%$ advantage over the total project cost when compared to traditional methods (design bid build).

- Design build methods provide cost overrun due to changes in work that are reduced by $5.2 \%$ compared to traditional methods

- The design build method gives $33 \%$ total project completion time compared to traditional methods.

The project is a temporary business that uses existing resources that have goals and objectives and are completed within a certain period [4]. Whereas a construction project is a series of interrelated activities to achieve certain goals (buildings / construction) within certain time, cost and quality limits.

Construction projects always require resources (resources), namely man (human), material (building material), machine (equipment), method (method of implementation), money (money), information (information), and time (time).

In general the design and build process can be divided into several phases [6]:

1) The planning process

2) Procurement process

3) The design development process

4) The process of physical construction of work (Build)

5) The process of monitoring and control (Monitoring \& Controling)

6) Closing process

\subsection{Project owner}

Toni Alam (2011: 61) The owner of the project is the party who plays a role in determining the type of project and providing the budget required during the project. In addition, the Owner can also be involved in project planning and supervision. Project owners can consist of individuals, business groups or governments that have the ability to fund the project as a whole.

\subsection{Planner-builder}

Planner-Builder in this case is the Design Builder Team is the party of goods / service providers appointed by the project owner or Owner to carry out the design project. In the design project after the contract is signed by both parties, the design builder as the executor of the work will make the design of the work in accordance with the TOR (Terom of Refrence) / KAK (Terms of Reference) compiled by the Owner [7].

\subsection{Project characteristics}

Toni Alam $(2011 ; 71)$ Characteristics of a project include the uniqueness of the project itself, naturally temporary, which has a limited grace period (there is the beginning and end of the project). The project is considered complete when the final project goal has been achieved and in accordance with the requirements. The success of a project is determined by the expectations of all stakeholders.

\subsection{Benchmark project performance}


Determining factors as a measure of performance of a project are [8]:

- Cost

Implementation of a project requires costs. Costs used to work on a project must not exceed the available budget.

- Time (scheduling):

The implementation of a project has a targeted time span and must be met. This is with the consideration that if the completion of the project is longer then the losses in terms of costs incurred will be even greater.

- Quality (quality);

Each project activity must produce a quality end result, in accordance with the plan and must meet the technical specifications in accordance with the requirements of the Owner.

Besides the 3 (three) main factors above, there are still additional criteria for success in measuring the performance of a project, namely (Anthony D. Sunger and Keith R. Molenaar):

- Meet the expectations of service users (conforms the user's expectation); Project work completed can meet the expectations of project service users.

- High quality employment (high quality of workmanship): During the project, meet all aspects required according to labor standards.

- Minimize the occurrence of disruption to construction (minimized construction aggravation): During the project, meet all aspects required according to labor standards.

\subsection{Project risk}

Events that will hinder the achievement of project performance targets are called project risks. To improve the time performance of the project management steps need to be taken, including identifying what risk factors can cause delays in project implementation. Besides that it is necessary to carry out an analysis and response in managing these risk factors so that the company is able to achieve faster and more timely performance [9].

Some determining aspects in the implementation of design work include [10]:

Tunggal The sole responsibility given by the employer to the executor of the work for financing, scheduling and achieving overall project implementation performance.

- Faster completion of work due to collaborative project management to get work done faster and reduce potential problems.

- Minimize changes in work (change order); work changes that occur due to design that does not take into account certain situations and obstacles.

Otensi Potential for better quality work; the design build method meets the requirements for performance rather than the minimum planning requirements [11].

- Reducing the occurrence of risks for job owners; implementing design and build work assumes risks to be completed.

- Reduction of administrative burden; the focus remains on the project as a whole, not on separate functions.

- Potential for cost savings; where an integrated team will be able to implement solutions and problem solving in an efficient and innovative way.

- Fewer lawsuits; Project / job owner can reduce or even eliminate lawsuits with a closed warranty gap.

The following figure shows the relationship between the Project Owner and the Implementer-Builder of design and build work

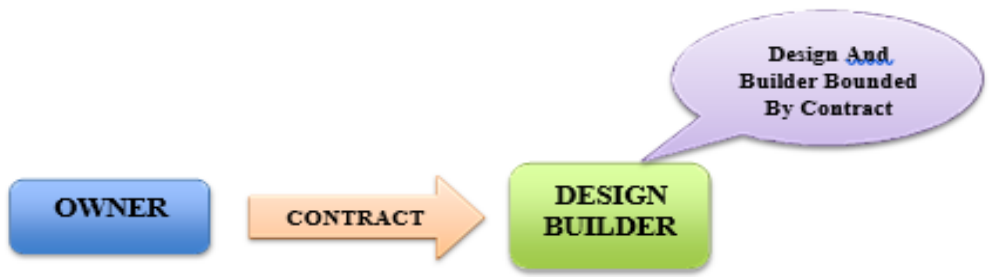

Fig. 1: Relationship between Project Owner and Implementer-Builder of Design and Build Work [12].

\begin{tabular}{|c|c|c|c|c|}
\hline No & Journal & Title & Method & Research result \\
\hline 1. & Qing Chen, Zhigang Jin, Bo Xia, Peng Wu and Martin Skitmore (2016) & $\begin{array}{l}\text { "Time and } \\
\text { Cost Perfor- } \\
\text { mance of } \\
\text { Design Build } \\
\text { Project" }\end{array}$ & $\begin{array}{l}\text { Using the } \\
\text { ANOVA } \\
\text { Method }\end{array}$ & $\begin{array}{l}\text { The result on the } \\
\text { design work gives relatively } \\
\text { good time performance, } \\
\text { more than } 75 \% \text { of the work } \\
\text { with the design work is } \\
\text { completed on time or ahead } \\
\text { of schedule. But in terms of } \\
\text { cost, only } 50 \% \text { of the design } \\
\text { work is overbudgeted }\end{array}$ \\
\hline 2. & Edmond W. M. Lam, Albert P. C. Chan and Daniel W. M. Chan, M. ASCE (2008) & $\begin{array}{l}\text { "Determinants } \\
\text { of Successful } \\
\text { Design-Build } \\
\text { Projects " }\end{array}$ & $\begin{array}{l}\text { Multiple } \\
\text { Regression } \\
\text { Analysis }\end{array}$ & $\begin{array}{l}\text { the nature of projects, effec- } \\
\text { tive project management } \\
\text { actions, and the adoption of } \\
\text { innovative management } \\
\text { approaches are critical } \\
\text { success factors for design } \\
\text { projects. }\end{array}$ \\
\hline 3. & Pramen P. Shrestha, Ph.D., P.E., M. ASCE; and Medya Fathi, S.M. ASCE (2019) & $\begin{array}{l}\text { Impacts of } \\
\text { Change Or- } \\
\text { ders on Cost } \\
\text { and Schedule } \\
\text { Performance } \\
\text { and the Corre- } \\
\text { lation with }\end{array}$ & $\begin{array}{l}\text { Chi-square, } \\
\text { Pearson's } \\
\text { correlation } \\
\text { coefficients } \\
\text { and t tests } \\
\text { were used } \\
\text { to confirm }\end{array}$ & $\begin{array}{l}\text { Job changes have a signifi- } \\
\text { cantly lower effect on the } \\
\text { cost performance of the } \\
\text { Design and Build project } \\
\text { and have no effect on the } \\
\text { performance of the Design } \\
\text { and Build schedule. There- }\end{array}$ \\
\hline
\end{tabular}




\begin{tabular}{|c|c|c|c|}
\hline No Journal & Title & Method & Research result \\
\hline & $\begin{array}{l}\text { Project Size } \\
\text { of DB Build- } \\
\text { ing Projects }\end{array}$ & $\begin{array}{l}\text { the research } \\
\text { hypothesis }\end{array}$ & $\begin{array}{l}\text { fore, it can be stated that } \\
\text { Design and Build is a better } \\
\text { project method than con- } \\
\text { ventional contracts in terms } \\
\text { of generation of change } \\
\text { orders and has an impact on } \\
\text { cost and schedule overruns }\end{array}$ \\
\hline
\end{tabular}

Based on the three journals there is no explanation of The Effect Of Project Owners, Plan-Developers And Characteristics Of Projects On Airport Building Performance so that it can be said the findings of this study can be used as a nouvelty in adding scientific literature.

\section{Research metodology}

In this study the authors used the explanatory survey method. Based on the method and measurement and analysis of the data, this research is classified as a survey research (survey research), because it uses a questionnaire as its main source, and also as a quantitative research (quantitative research) [13].

\section{Results and discussion}

\subsection{Loading factor value analysis}

An loading factor value analysis is performed to see whether each indicator is valid for a variable. Indicator can be said to be valid if it has a loading factor value> 0.6. Analysis of the loading factor value is done with the help of SmartPLS software. The results of the analysis can be seen in Figure 2 and Table 1.

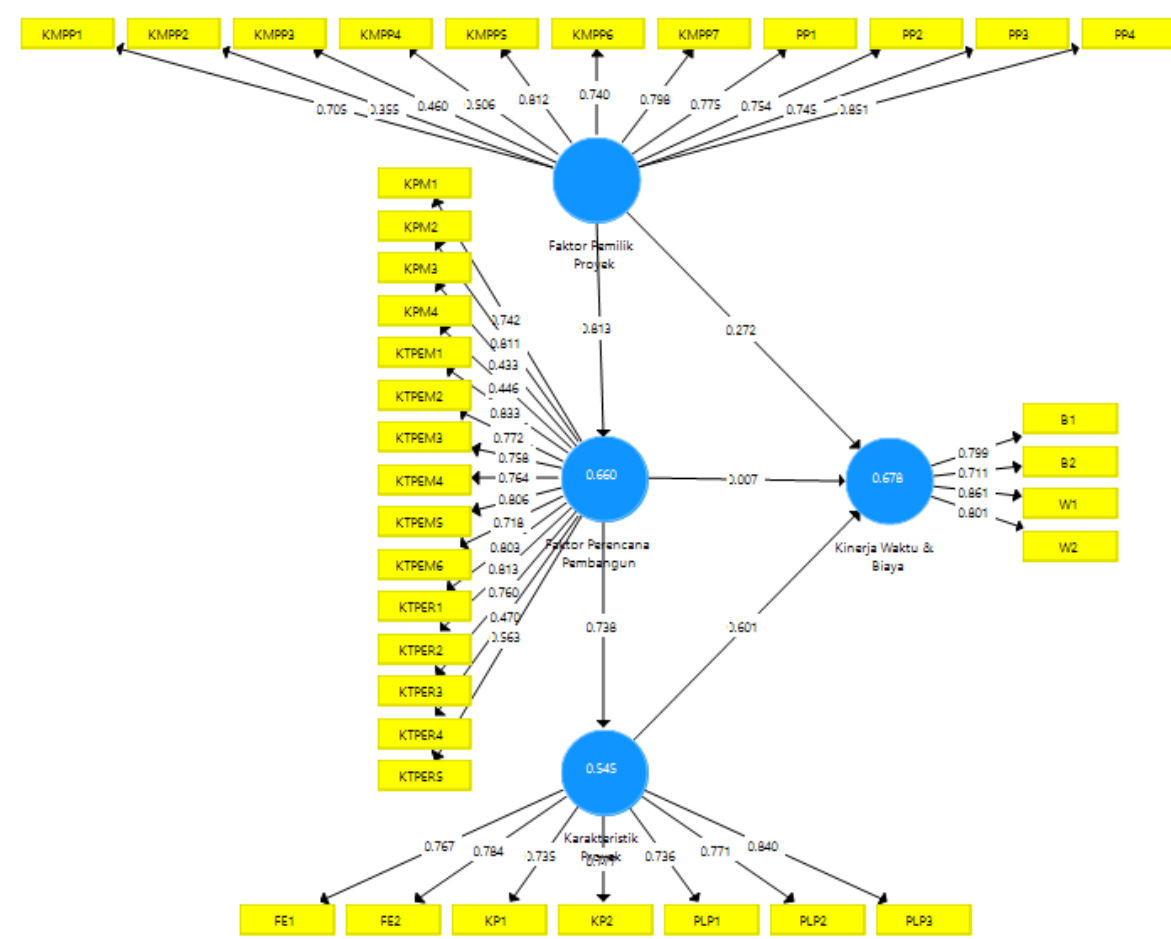

Fig. 2: Output Standardized Solution - Initial.

\begin{tabular}{lllll}
\multicolumn{5}{c}{ Table 2: Loading Factor Values - Initial } \\
\hline Indicator & Project Owner Factors & Planner Factor - Builders & Project Characteristics & Time \& Cost Performance \\
\hline KMPP1 & 0,705 & & & \\
KMPP2 & 0,355 & & \\
KMPP3 & 0,460 & & \\
KMPP4 & 0,506 & & \\
KMPP5 & 0,812 & & \\
KMPP6 & 0,740 & & \\
KMPP7 & 0,798 & & \\
PP1 & 0,775 & & \\
PP2 & 0,754 & & \\
PP3 & 0,745 & 0,803 & \\
PP4 & 0,851 & 0,813 & \\
KTPER1 & & 0,760 & \\
KTPER2 & & 0,470 & \\
KTPER3 & & 0,563 & \\
KTPER4 & & & \\
KTPER5 & & & \\
\end{tabular}




\begin{tabular}{|c|c|c|c|c|}
\hline Indicator & Project Owner Factors & Planner Factor - Builders & Project Characteristics & Time \& Cost Performance \\
\hline KTPEM1 & & 0,833 & & \\
\hline КТРЕМ2 & & 0,772 & & \\
\hline KTPEM3 & & 0,758 & & \\
\hline KTPEM4 & & 0,764 & & \\
\hline KTPEM5 & & 0,806 & & \\
\hline KTPEM6 & & 0,718 & & \\
\hline KPM1 & & 0,742 & & \\
\hline KPM2 & & 0,811 & & \\
\hline KPM3 & & 0,433 & & \\
\hline KPM4 & & 0,446 & & \\
\hline PLP1 & & & 0,736 & \\
\hline PLP2 & & & 0,771 & \\
\hline PLP3 & & & 0,840 & \\
\hline KP1 & & & 0,735 & \\
\hline KP2 & & & 0,777 & \\
\hline FE1 & & & 0,767 & \\
\hline FE2 & & & 0,784 & \\
\hline B1 & & & & 0,799 \\
\hline B2 & & & & 0,711 \\
\hline W1 & & & & 0,861 \\
\hline W2 & & & & 0,801 \\
\hline
\end{tabular}

Based on the picture above, it can be seen that there are several indicators that are not valid, namely indicators that have a loading factor value <0.6, namely:

$\begin{array}{lll}- & \text { KMPP2 } & =0,355 \\ - & \text { KMPP3 } & =0,460 \\ \text { - KMPP4 } & \text { KPM3 } & =0,506 \\ \text { - KPM4 } & =0,433 \\ \text { - KTPER4 } & =0,446 \\ \text { KTPER5 } & =0,470 \\ & & =0,563\end{array}$

Therefore, for further analysis these indicators will be written off in the model. The results of the standardized solution and the loading factor value of each indicator in the revised model are shown in Figure 3 and table 2.

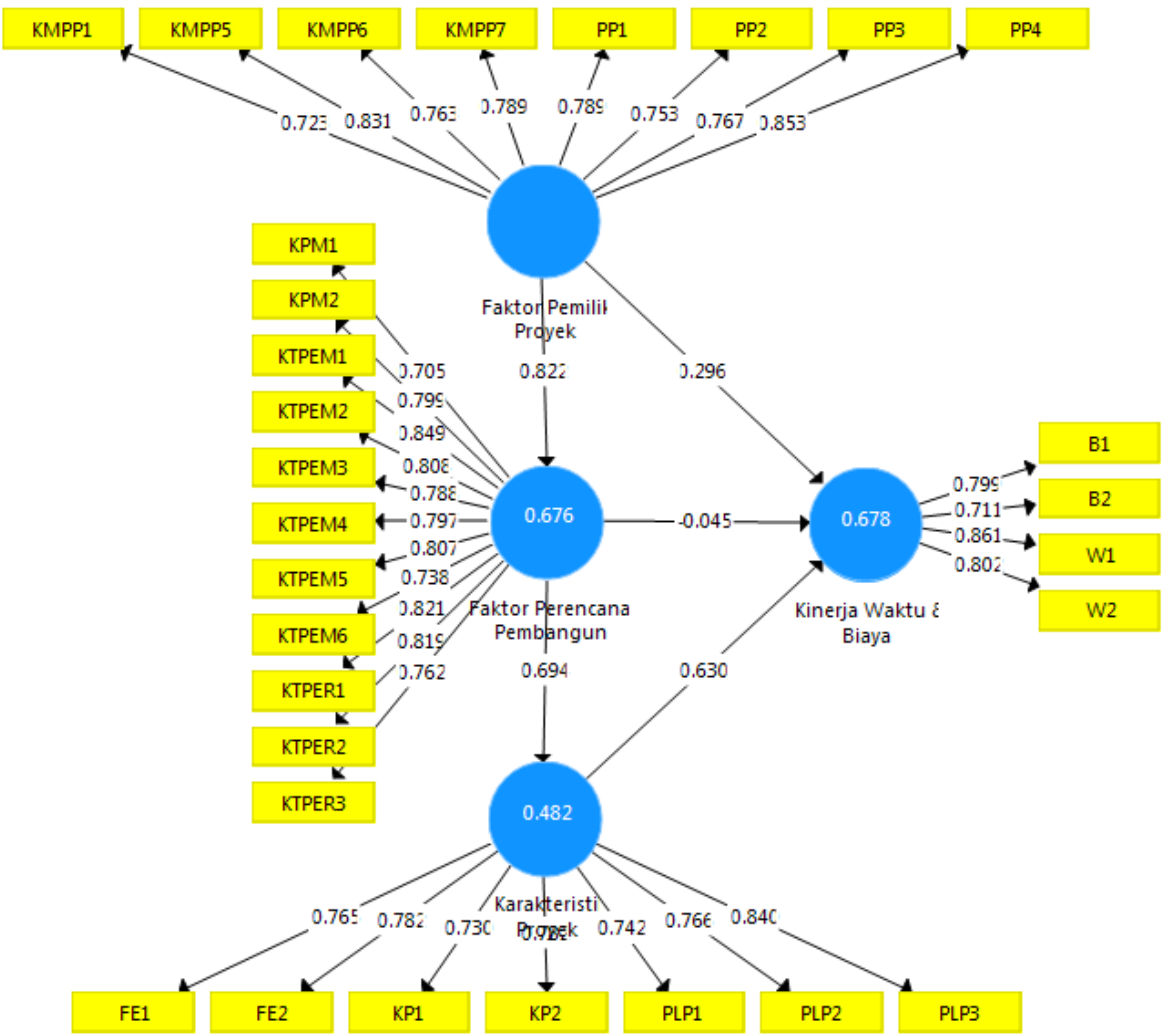

Fig. 3: Output Standardized Solution - Final.

Table 3: Value of Loading Factor - Final

\begin{tabular}{lllll}
\hline Indicator & Project Owner Factors & Planner Factor - Builders & Project Characteristics & Time \& Cost Performance \\
\hline KMPP1 & 0,723 & & \\
KMPP5 & 0,831 & & \\
KMPP6 & 0,763 & & \\
KMPP7 & 0,789 & & \\
PP1 & 0,789 & & \\
\hline
\end{tabular}




\begin{tabular}{|c|c|c|c|c|}
\hline Indicator & Project Owner Factors & Planner Factor - Builders & Project Characteristics & Time \& Cost Performance \\
\hline PP2 & 0,753 & & & \\
\hline PP3 & 0,767 & & & \\
\hline PP4 & 0,853 & & & \\
\hline KTPER2 & & 0,819 & & \\
\hline KTPER3 & & 0,762 & & \\
\hline KTPEM1 & & 0,849 & & \\
\hline KTPEM2 & & 0,808 & & \\
\hline KTPEM4 & & 0,797 & & \\
\hline KTPEM5 & & 0,807 & & \\
\hline KTPEM6 & & 0,738 & & \\
\hline KPM1 & & 0,705 & & \\
\hline KPM2 & & 0,799 & & \\
\hline PLP1 & & & 0,742 & \\
\hline PLP2 & & & 0,766 & \\
\hline PLP3 & & & 0,840 & \\
\hline KP2 & & & 0,782 & \\
\hline FE1 & & & 0,765 & \\
\hline FE2 & & & 0,782 & \\
\hline B1 & & & & 0,799 \\
\hline B2 & & & & 0,711 \\
\hline W1 & & & & 0,861 \\
\hline W2 & & & & 0,802 \\
\hline
\end{tabular}

The results in Figure 3 and table 2 above can be seen that all the loading factors of the indicator have a good value (>0.6). This means that each indicator is valid in measuring its construct.

\subsection{Outer model}

In evaluating the measurement model / outer model, validity and reliability testing, and discriminant validity will be tested.

To find out whether all indicators are valid and reliable in measuring the constructs / latent variables, then the validity test will be done using the Average Variance Extracted (AVE) analysis and the reliability test using the Composite Reliability (CR) analysis. All indicators are valid if it has a AVE value> 0.5 and is said to be reliable if it has a CR value>0.7. The AVE and CR values for each variable are shown in table 4.

Table 4: Composite Reliability and Average Variance Extracted Values

\begin{tabular}{lll}
\hline Variable & Composite Reliability & Average Variance Extracted (AVE) \\
\hline Project Owner Factors & 0,927 & 0,616 \\
Factors of Planning Team - Builders & 0,948 & 0,626 \\
Project Characteristics & 0,912 & 0,601 \\
Time \& Cost Performance & 0,873 & 0,632 \\
\hline
\end{tabular}

Based on the table above it can be seen that all indicators in each variable are valid and reliable. This can be seen from the CR value> 0.7 and AVE value> 0.5 .

After knowing that all variables have valid and reliable indicators, then proceed with discriminant validity analysis. Discriminant validity analysis was performed with a cross loading test. A construct can be said to be unique (different from other constructs), if all indicators have a higher loading factor value in the intended construct compared to the loading factor value in other constructs. Cross loading test results can be seen in table 5

Table 5: Cross Loading Test Results

\begin{tabular}{|c|c|c|c|c|}
\hline Indicator & Project Owner Factors & Planner Factor - Builders & Project Characteristics & Time \& Cost Performance \\
\hline KMPP1 & 0,723 & 0,584 & 0,376 & 0,397 \\
\hline KMPP5 & 0,831 & 0,739 & 0,558 & 0,535 \\
\hline KMPP6 & 0,763 & 0,681 & 0,506 & 0,570 \\
\hline KMPP7 & 0,789 & 0,648 & 0,519 & 0,482 \\
\hline PP1 & 0,789 & 0,640 & 0,559 & 0,446 \\
\hline PP2 & 0,753 & 0,547 & 0,414 & 0,449 \\
\hline PP3 & 0,767 & 0,640 & 0,666 & 0,684 \\
\hline PP4 & 0,853 & 0,658 & 0,619 & 0,682 \\
\hline KTPER1 & 0,701 & 0,821 & 0,510 & 0,508 \\
\hline KTPER2 & 0,712 & 0,819 & 0,524 & 0,586 \\
\hline KTPER3 & 0,568 & 0,762 & 0,443 & 0,438 \\
\hline KTPEM1 & 0,677 & 0,849 & 0,524 & 0,429 \\
\hline KTPEM2 & 0,614 & 0,808 & 0,504 & 0,413 \\
\hline КТРЕМ3 & 0,625 & 0,788 & 0,561 & 0,513 \\
\hline KTPEM4 & 0,690 & 0,797 & 0,568 & 0,406 \\
\hline KTPEM5 & 0,604 & 0,807 & 0,596 & 0,525 \\
\hline КTPEM6 & 0,711 & 0,738 & 0,561 & 0,624 \\
\hline KPM1 & 0,550 & 0,705 & 0,701 & 0,551 \\
\hline KPM2 & 0,666 & 0,799 & 0,510 & 0,480 \\
\hline PLP1 & 0,735 & 0,784 & 0,742 & 0,608 \\
\hline PLP2 & 0,313 & 0,356 & 0,766 & 0,650 \\
\hline PLP3 & 0,432 & 0,533 & 0,840 & 0,721 \\
\hline KP1 & 0,329 & 0,301 & 0,730 & 0,603 \\
\hline
\end{tabular}




\begin{tabular}{lllll}
\hline Indicator & Project Owner Factors & Planner Factor - Builders & Project Characteristics & Time \& Cost Performance \\
\hline KP2 & 0,739 & 0,740 & 0,782 & 0,567 \\
FE1 & 0,475 & 0,415 & 0,765 & 0,593 \\
FE2 & 0,540 & 0,473 & 0,782 & 0,582 \\
B1 & 0,441 & 0,394 & 0,596 & 0,799 \\
B2 & 0,747 & 0,702 & 0,624 & 0,711 \\
W1 & 0,455 & 0,426 & 0,690 & 0,861 \\
W2 & 0,509 & 0,463 & 0,618 & 0,802 \\
\hline
\end{tabular}

Based on table 5 it can be seen that the loading factor for constructors of Project Owner Factors (KMPP1 through PP4) has a loading factor on the Project Owner Factor construct higher than with other constructs. Likewise, the indicators in the constructor of the Planner Builder Factor (KTPER 1 through KPM2), Project Characteristics (PLP 1 through FE2), and Time and Cost Performance (B1 through W2), also have loading factor values in the construct itself compared to other constructs. This shows that each construct in this study is unique compared to other constructs.

This study aims to examine the relationship between project owner factors, planner-builder factors, and project characteristics on time \& cost performance. Based on the research model, it can be tested research hypotheses as shown in table 6 .

\begin{tabular}{lll}
\multicolumn{2}{c}{ Table 6: Research Hypothesis Tests } \\
\hline Relationship & Direct Influence & P Values \\
\hline Project Owner Factors $\rightarrow$ Pembang Builder Planning Factors & 0,822 & 0,000 \\
Project Owner Factors $\rightarrow$ Proyek Project Performance (Time \& Cost) & 0,296 & 0,188 \\
Planner-Builder Factor $\rightarrow$ Characteristics of the project & 0,694 & 0,000 \\
Planning Factors - Builders $\rightarrow$ Proyek Project Performance (Time \& Cost) & $-0,045$ & 0,828 \\
Project Characteristics $\rightarrow$ Proyek Project Performance (Time \& Cost) & 0,630 & 0,000 \\
\hline
\end{tabular}

Based on table 6 above, it can be concluded that the factor of the project owner has a positive relationship with the factors of the planner of construction (H1). This is indicated by the effect value of 0.822 . If the project owner factor variable increases by 1 and the other variables are constant, it will increase the value of the builder planner factor variable by 0.822 . However, if you see a p-value of 0,000 ; it can be concluded that the influence of the project owner's factors on the planner's builder factor is significant (p-value $<0.05$ ).

Based on table 6 above, it can be concluded that the factor of the project owner has a positive relationship on project performance (time $\&$ cost) (H2). This is indicated by the effect value of 0.296. If the project owner factor variable increases by 1 and other variables are constant, it will increase the value of the project performance variable (time $\&$ cost) by 0.296 . However, if you see a $p$-value of 0.188 ; it can be concluded that the influence of project owner factors on project performance (time \& cost) is not significant ( $p$-value $>0.05$ ).

Based on table 6 above, it can be concluded that the planner-builder factor has a positive relationship with project characteristics (H3). This is indicated by the effect value of 0.694 . If the planner-builder factor variable increases by 1 and the other variables are constant, it will decrease the value of the project characteristic variable by 0.694 . However, if you see a p-value of 0,000 ; it can be concluded that the influence of the planner-builder factor on project characteristics is significant ( $\mathrm{p}$-value $<0.05$ ).

Based on table 6 above, it can be concluded that the planner-builder factor has a negative relationship on project performance (time $\&$ cost) (H4). This is indicated by the effect value of -0.045 . If the planner-builder factor variable increases by 1 and the other variables are constant, it will decrease the value of the time and cost performance variable by 0.045 . However, if you see a p-value of 0.828 ; it can be concluded that the influence of the planner-builder factor on project performance (time \& cost) is not significant (p-value>0.05).

Based on table 6 above, it can be concluded that the characteristics of the project have a positive relationship on project performance (time \& cost) (H5). This is indicated by the effect value of 0.630 . If the project characteristic variable increases by 1 and the other variables are constant, it will increase the value of the project performance variable (time and cost) by 0,630 . If you see a p-value of 0,000 ; it can be concluded that the influence of project characteristics on project performance (time $\&$ cost) is significant ( $p$-value $<0.05$ ).

Based on the value of its influence, it is known that the highest influence affecting project performance (time and cost) is the characteristics of the project, which is equal to 0.630 . This shows that the characteristics of the project, including defining the scope of the project, the complexity of the project, and external factors are important for the completion of the project in accordance with the planned time and cost

\section{Conclusion}

Based on the results of the study, the following conclusions are obtained:

1) The project owner factor has a positive and significant influence on the factors of the planning planner, thus the project owner factor consisting of the ability of the owner management and the procurement process is able to contribute positively to the factors of the planning planner consisting of the ability of the planning team, the ability of the building team and the ability of the project manager ;

2) The Project Owner Factor has a positive but not significant effect on Airport Project Performance (Cost \& Time), thus the project owner factor consisting of owner management capability and the procurement process is able to contribute positively to the Airport Project (Cost \& Time) Performance;

3) Planner Factors - Builders consisting of the ability of the planning team, the ability of the building team and the ability of the project manager have a positive and significant influence on the characteristics of the project which consists of defining the scope of the project, project complexity and external factors;

4) Planner Factor - Builders have a very small and insignificant negative effect on Airport Project Performance (Cost \& Time), thus the planner-builder factor which consists of the ability of the planning team, the ability of the building team and the ability of the project manager does not significantly affect the results of the Performance Airport (Cost \& Time) Projects;

5) Project Characteristics have a positive and significant influence on Project Performance (Cost \& Time), thus understanding the project characteristics which consist of defining the scope of the project, project complexity and external factors able to contribute positively and significantly to the results of the Project Performance (Cost \& Time) of the Airport;

6) Project owner factors, planners-builders and project characteristics, simultaneously, have an influence on Airport Project Performance (Cost and Time). These three things have their respective roles and contributions towards the completion of the design project at the airport. 


\section{References}

[1] Alam, Toni. (2011). Identifikasi faktor-faktor risiko proyek rancang bangun (design and build) pada PT XYZ yang berpengaruh terhadap kinerja waktu.

[2] Yuwono, B. E. (2009). Faktor Penentu Kesuksesan Proyek Rancang-Bangun. Jurnal Teknik Sipil dan Perencanaan, 10(1), $39-46$.

[3] Tarigan, A. M., Abdullah, A., \& Rani, H. A. (2018). Faktor-Faktor Risiko Design and Build Yang Mempengaruhi Kesuksesan Proyek Rehabilitasi Total Gedung Pendidikan Di Provinsi Daerah Khusus Ibukota Jakarta. Jurnal Arsip Rekayasa Sipil dan Perencanaan, 1(2), 156-165. https://doi.org/10.24815/jarsp.v1i2.10962.

[4] Dianita Ratna K ST, M. T., \& Ir, N. H. (2016). Analisa Faktor Penyebab Keterlambatan Progress Terkait Dengan Manajemen Waktu (Studi Kasus: Pelaksanaan Pembangunan Gedung UPT PP Politeknik Negeri Semarang). Wahana Teknik Sipil: Jurnal Pengembangan Teknik Sipil, 21(02).

[5] Lam, E. W., Chan, A. P., \& Chan, D. W. (2008). Determinants of Successful Design-Build Projects. Journal of Construction Engineering and management, 134(5), 333-341. https://doi.org/10.1061/(ASCE)0733-9364(2008)134:5(333).

[6] Chen, Q., Jin, Z., Xia, B., Wu, P., \& Skitmore, M. (2015). Time and cost performance of design-build projects. Journal of Construction Engineering and Management, 142(2), 04015074. https://doi.org/10.1061/(ASCE)CO.1943-7862.0001056.

[7] Alaydrus, A. M., \& Hardjomuljadi, S. (2019). Analisis Faktor Keterlambatan Dimulainya Pelaksanaan Proyek Konstruksi Pada Model Kontrak Rancang Bangun. Konstruksia, 10(1), 95-116.

[8] Akter, S., D'Ambra, J. \& Ray, P. (2011). Trustworthiness in mhealth information services: an assessment of a hierarchical model with mediating and moderating effects using partial least squares (PLS). Journal of the American Society for Information Science and Technology, 62 (1), 100-116. https://doi.org/10.1002/asi.21442.

[9] Chen, Q., Jin, Z., Xia, B., Wu, P., \& Skitmore, M. (2015). Time and cost performance of design-build projects. Journal of Construction Engineering and Management, 142(2), 04015074. https://doi.org/10.1061/(ASCE)CO.1943-7862.0001056.

[10] Fahirah, F., Adi, T. J. W., \& Anwar, N (2013). Identifikasi Kelemahan Metode Earned Value pada Pengukuran Kinerja Biaya dan Waktu Proyek Konstruksi. JOURNAL TEKNIK SIPIL DAN INFRASTRUKTUR, 3(2).

[11] Gunarso, g., \& sungkono, k. K. D. Analisis resiko tahap engineering design pada pembiayaan pekerjaan konstruksi proyek epc (Studi Kasus: Asam-Asam CPP And OLC Project, PT. Krakatau Engineering).

[12] Hoseingholi, M., \& Jalal, M. P. (2017). Identification and Analysis of Owner-Induced Problems in Design-Build Project Lifecycle. Journal of Legal Affairs and Dispute Resolution in Engineering and Construction, 9(2), 04516013. https://doi.org/10.1061/(ASCE)LA.1943-4170.0000206.

[13] Liu, J., Xie, Q., Xia, B., \& Bridge, A. J. (2017). Impact of design risk on the performance of design-build projects. Journal of Construction Engineering and Management, 143(6), 04017010. https://doi.org/10.1061/(ASCE)CO.1943-7862.0001299. 